\title{
El retrato de los «negros brujos». Los archivos visuales de la antropología afrocubana (1900-1920)
}

\section{The «Negros Brujos» portrait. Visual Archives of Afro-Cuban Anthropology}

\author{
Jorge Pavez Ojeda \\ Instituto de Investigaciones Arqueológicas \\ y Museo, Universidad Católica del Norte. San Pedro de Atacama, Chile \\ jpavez@ucn.cl
}

(

Resumen • Proponemos mostrar aquí el lugar que ocupó la imagen fotográfica en la elaboración de los imaginarios africanistas en las primeras décadas del siglo $\mathrm{XX}$ en Cuba. A partir de la revisión de algunas obras de la antropología cubana, destacaremos los procedimientos por los cuales las fotografías fueron usadas y valoradas como evidencias de las teorías del "atavismo» y las "supervivencias» africanas en Cuba, a partir de estereotipos occidentales aplicados a la estética de los llamados «negros brujos». El registro de sujetos inferiorizados por su condición racial, criminalizados por sus prácticas religiosas, dejó un corpus fotográfico que da cuenta de estos intentos por controlar los afectos de la fotografía por medio de dispositivos textuales, y a la vez, muestra la irreductibilidad de la imagen a estos dispositivos.

Palabras claves: fotografía policial, archivo afrocubano, historia de la antropología, estética de la brujería, Cuba.

Abstract - Through this article, I will illustrate the place occupied by the photographic image in the elaboration of the Africanist imaginaries by Cuban anthropologists between 1900 and 1920. Through the reading of some bibliographic works of Cuban anthropology, I will enhance the procedures, by which photographs were used and were valuated as illustrations of the Afro-Cuban "atavism» and «surviving» theories. This photographic corpus allows showing the attempts to control the affection of photography by means of textual devices. The deconstruction of these devices shows the irreducibility of the photography of alterity.

Keywords: criminal photography, afro-cuban records, history of anthropology, witchcraft aesthetic, Cuba. 


\section{INTRODUCCIÓN}

La antropología americana, al igual que la europea, ha abordado históricamente los sujetos de origen africano desde dos perspectivas: una, bajo la condición de cuerpos-objetos de las manipulaciones y clasificaciones médicas (el examen médico como producción de documentos); otra, la de corpus-textos de mitos, nombres y ritos (la búsqueda y extracción de los documentos existentes o la producción de los mismos) (Foucault, 1966; Stocking, 1968; Clifford, 1995; Pavez, 2007). Es bajo esta segunda perspectiva que fueron progresivamente valoradas las dimensiones estéticas de la alteridad en Latinoamérica. La mirada médica sobre los cuerpos se apoyó tempranamente en la cámara fotográfica, al punto de identificarse con ella, pero intentó siempre controlar las afecciones estéticas de esas imágenes. La observación médica encontró así en la fotografía, al igual que la llamada «policía científica», la definición de su precisión y objetividad, como defensa contra el pathos de los sujetos (Didi-Huberman, 2007). Al mismo tiempo, la fotografía constituyó una herramienta clave para las «economías visuales» de la alteridad social y cultural en Latinoamérica, fuertemente ancladas en los discursos raciológicos (Poole, 2000). En este artículo, queremos analizar la forma en que los antropólogos en Cuba, médicos y abogados de formación, se apropiaron de las imágenes de la «fotografía judicial» para afirmar sus discursos seudo-científicos sobre la raza negra, buscando en los retratos de afrocubanos la recurrencia y repetición de una serie de caracteres físicos que se creyó permitían identificar prácticas culturales y sociales asociadas a estos rasgos. Como veremos, estas operaciones de apropiación intentaron transformar los valores estéticos de los sujetos retratados en índices de estereotipos visuales criminalizados para, de esta manera, controlar los afectos miméticos generados por la imagen fotográfica.

Las primeras fotografías de negros africanos y criollos en Cuba se las debemos a las investigaciones del médico francés Henri Dumont, quien se interesó en el estudio de los esclavos para la inmunización de sus cuerpos biológicos, concluyendo prontamente en la necesidad de conocer su lengua, historia y religión para entender sus patologías (Dumont, 1915-16; Mestre, 1999). Su trabajo reúne los resultados de las observaciones etnográficas, fotografías y encuestas lingüísticas, religiosas y étnicas realizadas durante su estadía de dos años en Cuba (1864-1866), cuando ejercía como médico de esclavos en las plantaciones de Cárdenas, Colón y La Habana (Dumont, 1922). ${ }^{1}$

Su acucioso trabajo de documentación permite vincularlo a la tendencia «etnológica» liderada por Armand de Quatrefages en la Sociedad de Antropología de París, y que cohabitaba minoritariamente con el poligenismo y la antropometría de Paul Broca (Delgado García, 2001 y 2003). En sus «Instructions pour la recherche anthropologique» (1862), Quatrefages pone especial acento en dos aspectos bien desarrollados por Dumont en Cuba: la investigación sobre las patologías y el uso de la fotografía para la identificación y clasificación de las razas, incluyendo recomendaciones sobre tomas de frente y de perfil de aquellos que representen «mejor» un determinado «tipo racial», representaciones nor-

Los documentos de Dumont son encontrados y entregados a Fernando Ortiz por su discípulo Israel Castellanos en 1915. Este último realizará su traducción del francés y las notas críticas para su publicación en la Revista Bimestre Cubana (1915-1916), y luego su reedición como libro en 1922. Estos documentos conforman un dossier muy completo que fue presentado en la Sociedad de Amigos del País, institución cubana de intereses ilustrados, en 1876, pero publicados mucho más tarde. 
malizadoras cuya repetición mecánica y estandarizada buscaba realizar el valor indicial de la fotografía para la producción de estereotipos. Quatrefages defendía también una tesis que tendrá gran influencia en países como México y Cuba, a través de representantes como Dumont, la cual señala que la cohabitación de razas de diferentes grados de evolución en un mismo territorio permitía que aquellas consideradas inferiores alcancen un mayor desarrollo evolutivo (Urias, 2000: 81-5). A partir del trabajo de Dumont en Cuba, se iniciará la institucionalización de la antropología cubana, creándose la Cátedra de Antropología de la Universidad de La Habana y posteriormente un Museo de Antropología. A finales de siglo se observan dos principales preocupaciones de la antropología institucional cubana: por un lado, el hallazgo y clasificación de restos arqueológicos de indocubanos, y por otro, la antropometría inspirada de la tradición raciológica francesa, ambos atravesados por un mismo paradigma raciológico (Montané, 1909; Mestre, 1999; Delgado García, 2004). Es aquí cuando se observa una tensión entre dos tendencias que cruzan los intereses de investigación de los antropólogos. Esta tensión estará en sintonía con los debates de la antropología europea, que, privilegiando primero el estudio bio-médico de los cuerpos, irá derivando luego hacia el estudio de las determinaciones sociales de los fenómenos culturales (Pick, 1993; Muchielli, 1998; Legrand, 2003). A principios del siglo XX, el abogado Fernando Ortiz y el médico Israel Castellanos representan en Cuba ambas tendencias, y un interés común en la fotografía plasmado en la edición de los documentos fotográficos de Henri Dumont.

A estas alturas, la práctica fotográfica se había vuelto consustancial al desarrollo de las ciencias (o seudo-ciencias) humanas, por su utilidad para los proyectos vinculados a la identificación de «tipos» sicológicos, sociales y/o raciales (biológicos) (Batut, 1887; Londe, 1896). A partir de los años ochenta del siglo XIX, la invención de la instantaneidad mecánica liberó a la fotografía de los códigos y de la temporalidad del retrato pintado. La «máquina de visión» se volverá «el instrumento de tres instituciones fundamentales de la vida y la muerte (justicia, ejército, medicina)» y será sistemáticamente aplicada al control de criminales, soldados y enfermos en sus lugares de reclusión (cárceles, regimientos, hospitales) (Virilio, 1989: 59). No es casualidad que este periodo vea el ascenso de la antropología criminal como disciplina llamada a responder a las demandas de orden y homogeneización de sociedades nacionales en proceso de formación (como la Italia de Garibaldi o la Cuba de Martí) y transformación social (crecimiento urbano y proletarización como en España o Francia) (Pick, 1993; Pavez, 2007: 66-102). La antropología criminal practicada por Cesare Lombroso se abastecerá entonces de las fotografías producidas por el sistema judicial y penitenciario, para la ilustración de sus teorías (Lombroso, $1887 ; 1898)$. Se entiende así el entusiasmo en torno a esta nueva «memoria artificial de la humanidad» por su ayuda a la disciplina como «registrador automático e imparcial de los acontecimientos» (Locard, 1904). Entusiasmo que no empaña siquiera la confesión del mismo Alphonse Bertillon, impulsor de las nuevas técnicas de reconocimiento e identificación civil y penal, al señalar que «en ninguna parte, el acto de reconocimiento se hace de manera tan brutal como en el ejercicio de la fotografía judicial» (Bertillon, 1890, en Piazza, 2000).

En lo que sigue, proponemos revisar el trabajo de los antropólogos cubanos Fernando Ortiz e Israel Castellanos para analizar el uso que le dieron a los documentos fotográficos en sus obras, en tanto impulsores y propagadores de las teorías lombrosianas en Cuba. El abogado Ortiz y su discípulo el médico Castellanos desarrollaron su trabajo 
criminológico en las primeras décadas del siglo XX en La Habana y compartieron una serie de perspectivas criminológicas como la:

minimización de la sociogénesis del delito; [la] medicalización (y/o psiquiatrización) del derecho penal y de la sociedad en su conjunto; [la] propugnación del prevencionismo y de la defensa social; [la] desculpabilización del poder burgués; y [la] justificación científica de la ideología del intervencionismo radical (Marqués de Armas, 2004: nota 9).

Sin embargo, ambos criminólogos usaron y expusieron de diferentes maneras los recursos fotográficos del aparato judicial-penitenciario de la joven república cubana. Como los documentos producidos por este aparato constituyen uno de los principales archivos fotográficos de los sujetos afrocubanos de ese periodo, proponemos mostrar qué tipo de indexación, clasificación y lectura dieron estos antropólogos a las imágenes fotográficas para la representación visual de los tipos sociales que pretendieron identificar, en lo que constituye el corpus fundacional de la antropología afrocubana.

\section{FERNANDO ORTIZ Y EL BRUJO BOCÚ: SPECTRUM Y NOEMA DE UN RETRATO}

Por sus estudios en Madrid y Turín, el contacto del abogado Fernando Ortiz con las escuelas italiana y española de antropología criminal (bajo la supervisión de sus maestros Cesare Lombroso y Rafael Salillas) lo llevará a valorar la fotografía penitenciaria y judicial como fuente para el estudio de la antropología "afrocubana», según el neologismo propuesto por él. En su primer libro, Hampa afrocubana. Los Negros Brujos, publicado en 1906 en Madrid, con prólogo de Lombroso, Ortiz hace explícitas sus pretensiones de "profilaxis del delito», "higienización social», y "desafricanización» de los «antros» afrocubanos, proponiendo un «programa de erradicación de la brujería» (Ortiz, 1995: 181-95). Con este fin, realiza una aplicación revisada de las clasificaciones lombrosianas del «criminal nato», para adaptarla a los «delincuentes» afrocubanos, es decir los «brujos» africanos.

Siguiendo a Enricco Ferri y Armand Lacassagne, Ortiz propone la definición de dos clases de brujos, «corregibles» e «incorregibles», o «brujos por costumbre» y «brujos fanáticos». Aunque admite que «estas dos categorías no son ni pueden ser perfectamente delimitadas», ya que esto ocurre con «todas las categorías y clasificaciones imaginables de delincuentes», el tratamiento punitivo que propone para cada uno es notoriamente diferente. Los primeros, "principalmente criollos», podrían "abandonar sus prácticas supersticiosas en función del enraizamiento de su hábito parasitario», al igual que «los demás delincuentes habituales", "corregibles» (Ortiz, 1995: 194). Se observa así el paso de un concepto biológico, "parasitismo", a otro cultural, la "fuerza del hábito", que Edward Tylor había utilizado para explicar su teoría de las «supervivencias» (1871). Sobre la segunda clase en cambio, la de los brujos «incorregibles», entre los cuales se incluyen "de preferencia los antiguos africanos", pesará todo el determinismo hereditario y biológico del lombrosianismo más duro. De éstos, «no hay que esperar ninguna mutación en su sistema de ideas: son brujos y morirán como tales, son incorregibles» (Ortiz, 1995: 195). Y además de proponer la tipificación penal del delito de brujería (196), el autor señala la necesidad de un tratamiento punitivo especial para todo aquel identificado como 
brujo profesional o incorregible, como sería «el caso del brujo Bocú, asesino por pura brujería»: «el aislamiento perpetuo» en una "colonia penitenciaria» (195).

El caso Bocú aparece aquí, y en todo el libro de Ortiz, como un caso ejemplar vuelto símbolo de la campaña contra la brujería en la que participa el abogado lombrosiano, campaña varias veces activada por los medios de comunicación y los poderes públicos en los momentos políticos claves de la reivindicación de derechos de los negros en las primeras décadas de la república (Chávez, 1991; Helg, 1996). En 1904, Domingo Bocourt, conocido como Bocú, es acusado y apresado con otro afrocubano, Víctor Molina, el primero por haber encargado el asesinato de la niña blanca Zoila con el fin de curar a dos niñas negras, Adela y Juana; el segundo por haber ejecutado el crimen y la extracción del corazón. El asunto emocionó a la Cuba blanca de la época en momentos en que se discutía la participación de los negros en los asuntos nacionales (De la Fuente, 2001). Como han mostrado varios autores, la atmósfera social y política creada en torno al caso impedían considerar la posibilidad de inocencia de Bocourt y Molina (Helg, 1990: 241-50; Bronfman, 2002b; Palmié, 2002: 211-46). Un periodista en específico, Eduardo Varela Zequeira, de El Mundo de La Habana, contribuyó especialmente al ambiente de venganza negrofóbica creado en torno al caso, anticipándose a todas las investigaciones y reconstruyendo el caso tanto para la opinión pública como para los tribunales. ${ }^{2}$ A partir de entonces y hasta 1924, se conocerán veinticuatro casos de supuestos "crímenes rituales», en los cuales se repetirá a grandes rasgos el mismo procedimiento policial, judicial, político y mediático (Palmié, 2002: 211). La única diferencia será que Bocourt y Molina serán los primeros y únicos condenados a muerte y ejecutados, en 1906, año de abolición de la pena de muerte en Cuba y de publicación del libro de Ortiz.

En este libro Ortiz usará el expediente Bocú, que conoce sólo de segunda mano, ${ }^{3}$ para desplegar la teoría y los métodos de la antropología criminal en boga en Europa, e identificará el «brujo afrocubano» como un «tipo criminal» específico, reclamando acciones penales de «defensa social» contra la «hechicería» africana:

el asesinato de la niña Zoila debe interpretarse como un caso de simple hechicería; así como se cree en Africa que comiendo el cerebro de un caudillo enemigo se adquiere todo el valor de éste, y que el niño amamantado por muchas mujeres poseerá numerosas dotes intelectuales, así se habrá creído que el corazón de una niña, comido por una mujer estéril, había de ocasionar la fecundidad de ésta. Todo lo cual no impide la verosimilitud del hecho de haber sido ofrendados los miembros de la infeliz niña ante las imágenes de Santa Bárbara y del Anima Sola, de Shangó y de Eleguá (1995: 106).

\footnotetext{
El periodista imputó a Bocú el haber «salado» el cuerpo de la niña, lo que fue desmentido por las pericias, y evoca una supuesta confesión del crimen a su carcelero, el día antes de su muerte. Las pruebas en su contra nunca fueron sólidas, los testigos poco fiables, y la defensa ineficaz. Al principio, la niña Zoila desaparecida, Bocourt y otros miembros del cabildo de Congos Reales fueron arrestados, pero por falta de pruebas fueron exculpados. Luego, el periodista Varela establece la relación entre este caso y otro infanticidio, el de la joven Celia, del cual había sido acusado Sebastián Fernández, alias Tin-Tan. En los días de la sentencia de muerte de Tin-Tan, aparece el cadáver de la niña Zoila, lo que llevó a la recaptura de Bocourt y de los miembros de su cabildo.

3 Ortiz se encontraba en Italia mientras redactaba la obra, por lo que señala que para su estudio del caso, debió "prevalecerse únicamente de lo que ha sido ocasionalmente publicado por la prensa y de las informaciones solicitadas a algunos amigos». Entre estos amigos, destaca especialmente Emilio Hernández Gato (1995: 165-6).
} 
A la lectura de los etnógrafos africanistas coloniales, Ortiz suma la de la prensa cubana, a quien celebra por haber, "después del asesinato [,] escrutado el sub-suelo de nuestro pueblo» (1995: 104), y publica 55 recortes sobre «brujería» para el periodo 1902-1905, de los cuales 37 corresponden a 1904, año de la desaparición de la niña Zoila (capítulo VIII). De este modo, concluye que los brujos africanos habían introducido en Cuba el homicidio ritual y la violación de niñas vírgenes, justificando así la necesidad de «desafricanizar» un país cuyo progreso era amenazado por el "atavismo» primitivo africano. ${ }^{4}$ Es aquí pertinente el análisis de Keck sobre la construcción social de la brujería: «lo que importa en la brujería no son las acciones del brujo sino la creencia en que un brujo ha actuado y las palabras que se intercambian en un procedimiento infinito de acusación» (2002). La brujería aparece entonces en el triángulo constituido por aquel que se siente enfermo (la nación cubana en sus segmentos blancos), el que lo diagnostica (es el rol de los medios, y el periodista Varela a la cabeza), y el que lo desembruja (los «científicos» de la república, y Ortiz en primer lugar, seguido de Castellanos): «en cierto punto, no hay necesidad de brujo para que haya brujería» (Keck, 2002). Quizás habría que decir más bien que con la necesidad de brujería, aparecerá luego un brujo o más bien, la «imagen» del brujo. Porque este caso muestra precisamente el proceso por el cual se identifica al brujo, o mejor dicho, al africano que va a significar el «tipo ideal» del brujo, como «retrato" que combina un nombre, un rostro, una estética, un lugar, y una cultura material. Y este es precisamente el objetivo de la antropología criminal, el de instituir el dispositivo que Agamben llama una «máquina antropológica», por la cual estaría en juego «la producción de lo humano, a través de la oposición hombre/animal, humano/inhumano» (2006: 75).

Es por esto que el proyecto de identificación del brujo afro-cubano en las tipologías criminales va a requerir entonces la formación de una imagen del brujo, imagen que sirva como signo indicial para referir directamente al individuo brujo, sin necesidad de describirlo. La imagen elegida será aquí el retrato fotográfico de Bocú (lámina 1), como «ícono» del «tipo criminal» «descubierto» por Ortiz, un retrato "policial» que circuló profusamente en los diarios que cubrieron el caso (Bronfman, 2002b: 555). En esta imagen, Bocú está retratado de medio cuerpo sobre un fondo recortado, y su expresión compungida, propia de la situación de apresamiento en que se encuentra, será también usada para afirmar su opacidad como sujeto. La iconicidad del retrato de Bocú supone así una identificación del «tipo brujo» que es efecto de la fotografía, una identidad hecha posible por la «ideología mimética» que guía el uso positivista de la imagen fotográfica (Collingwood, 2009: 30). Pero a la vez, por ser la única fotografía inserta en la obra (entre 42 ilustraciones), este retrato funciona también como «índice», es decir, siguiendo la definición de Charles Peirce, como "signo que pone en contacto directamente, ‘físicamente, con el objeto", como «dedo apuntador» que ejerce una «fuerza hipnótica» o una «compulsión ciega hacia su objeto» y genera una «sensación de choque» con este (en Fumagalli, 1996). La «fuerza hipnótica» de la mirada de Bocú y la «sensación de choque» con su retrato, confirmarán para los antropólogos el valor indicial de esta fotografía para reafirmar la peligrosidad social de este «tipo incorregible». Se apela así a una afección sensible —el miedo- por medio de la indexación de una fisionomía a un texto criminalizador.

Estamos hablando aquí de una población de 505.000 negros y mulatos, entre los cuales 13.000 nacidos en África, frente a más de un millón de blancos (Censo de 1899, en Ortiz, 1995: 181). 


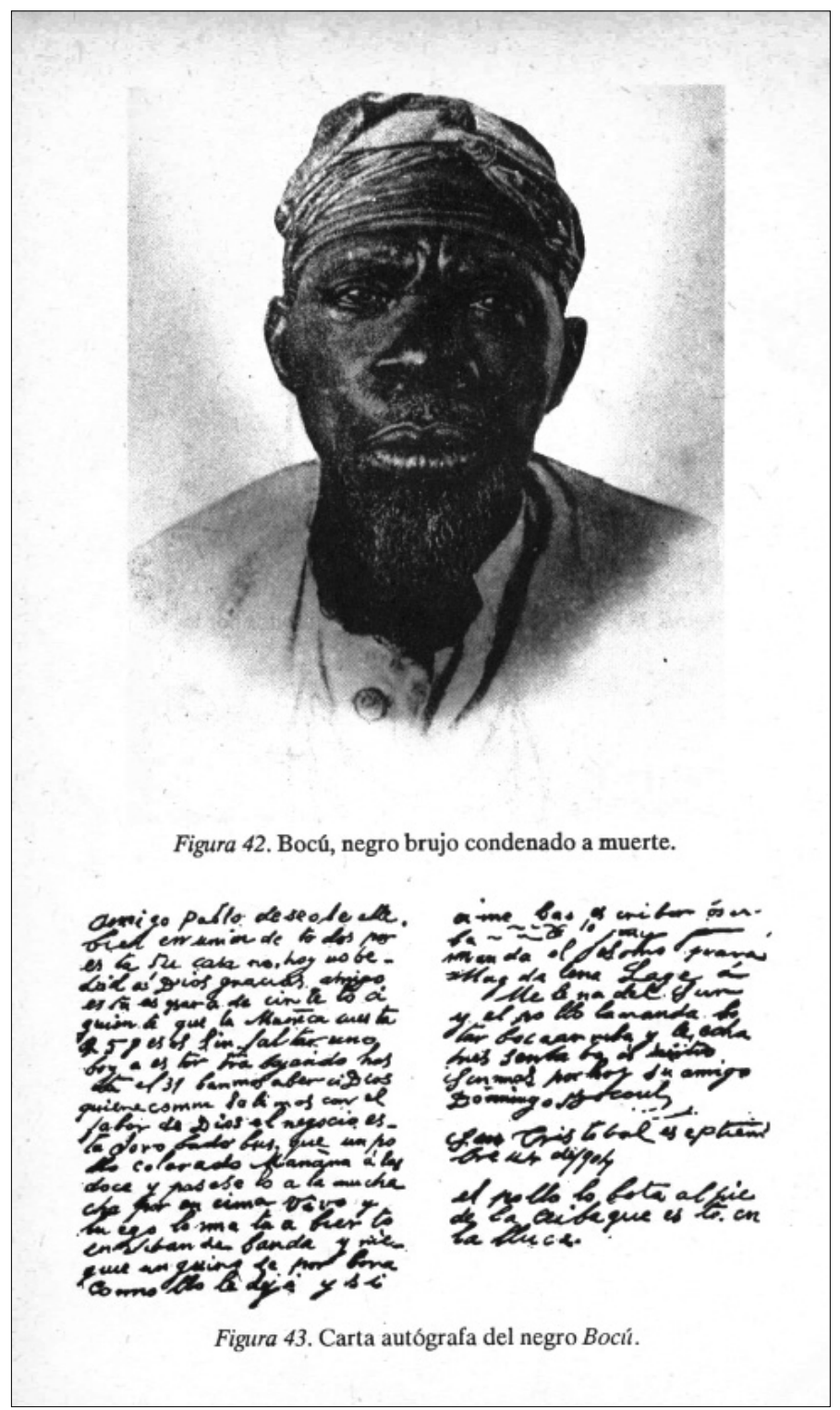

1. «Bocú, negro brujo condenado a muerte/ Carta autógrafa del negro Bocú» circa 1904 (Ortiz, 1995).

El día de la ejecución de Domingo Bocourt, Ortiz publica una crónica donde escribe «No seamos tan primitivos como para satisfacernos con la muerte sin sentido de Bocú», lamentando la aplicación de la pena capital a quien constituía un "valioso espécimen científico» (en Bronfman, 2002b: 556-8). Aunque Ortiz se opone claramente a la pena de muerte (y a las teorías de la «selección artificial» que la sustentan) lo hace con argumentos funcionales al desarrollo de su disciplina «científica»: lo que se trata de defender, lo que tiene sentido para él, no es tanto la vida de Bocourt, sino la vida de una ciencia que necesita «especímenes» vivos de las categorías que produce, en este caso la del brujo 
afrocubano. Interés que compartía con Lombroso, quien, al enterarse de la ejecucción de este ejemplar de "criminal nato" afrocubano, solicita a Ortiz el envío de la fotografía de Bocourt para su revista Archivio di psichiatria, scienze penali ed antropologia criminale (Bronfman, 2002b: 560).

Mientras que el cráneo del condenado será entregado al Museo de Antropología de la Universidad y fácilmente clasificado, su retrato parece ofrecer más resistencia a la clasificación que intenta recuperarlo como ícono de una mascarada, o como índice de un «atavismo» (lámina 1). Más allá de su carácter informativo, como índice o ícono de la «apariencia» de un negro brujo (cuestión que estará en el centro de las preocupaciones de Israel Castellanos), la publicación de la fotografía de Bocú por Ortiz busca generar un efecto de «desaparición», es decir, mostrar la imagen de lo que está llamado a desaparecer. Como en la fotografía del condenado a muerte que analiza Roland Barthes, ésta nos instala en el cruce de dos sensaciones enfrentadas en su representación del tiempo: el anuncio de la muerte próxima, la catástrofe futura, como vértigo de un spectrum que señala «él-va-a-morir» («la fotografía expresa la muerte en futuro»), y el noema de la fotografía que anuncia "esto-fue», la certeza de «una catástrofe que ya tuvo lugar» (1989: 165). Este doble efecto, del spectrum y el noema de la fotografía, permite ubicar la ambivalencia de Ortiz, para quien la catástrofe afecta una ciencia que necesitaba el «especimen» en su búsqueda de la «verdad científica». La inserción del retrato de Bocourt sugiere casi un homenaje a su memoria, un "valor cultual» de la fotografía, ya que implica la puesta en escena de su aura como «manifestación irrepetible de una lejanía» (Benjamin, 1991: 183). La lejanía en el tiempo y el espacio del sacerdote africano, el completo extrañamiento de su "aquí y ahora», no es aquí una potencia de la imagen reproducida química y mecánicamente, sino del rostro de un espectro con nombre propio. Como lo señaló Benjamin, el retrato de los seres ausentes o difuntos favorece el culto del recuerdo, ofrece "el último refugio del sentido ritual de la obra de arte», y esta distancia rememorada constituye en sí misma la experiencia estética (190). El spectrum puede así vencer el noema de la fotografía: su huella seguirá actuando sobre la realidad, aún alejada del contexto de su producción. Así, lo que fue sigue siendo, ya que por la imagen se prolonga el proceso del sujeto. Ante estas afecciones, y las necesidades de su ciencia de clasificaciones, Ortiz parece haber cedido a la "tentación icónica de la fotografía», aquella que «retoma la ambición de los pintores de elaborar una síntesis visual del rostro del individuo», mientras que la «afirmación indicial» implica privilegiar «la capacidad específica del medio de fijar una expresión efectiva y/o reveladora» y captar «infinitas secuencias de humores y condiciones de la persona» (Maresca, 1998). Pero en ambos casos, la fotografía es capturada por las clasificaciones criminológicas: como síntesis visual, el ícono producirá el «tipo brujo» y el efecto de su «reproductibilidad» fotográfica; como conjunto de secuencias expresivas, el índice indicará los rasgos generales de la identidad creada por el mecanismo fotográfico. El brujo entra así al campo de los referentes dispuestos para la identificación fotográfica (Collingwood, 2009: 26).

Dos años después de la muerte de Bocú, el agente de policía Rafael Roche publica una anécdota que, por efecto invertido, puede ayudar a esclarecer este aspecto anoemático asociado al valor de culto de los retratos. El texto describe su visita a la sede de una Sociedad de Protección Mutua situada en un suburbio de La Habana, y mientras observaba un altar, le llaman la atención 
dos tarjetas fotográficas ejecutadas en uno de los mejores establecimientos de su clase que hay en la Habana. Eran de dos niños blancos, por cuyos trajes se podía conjeturar que pertenecían á familias si no ricas, por lo menos acomodadas. ¿Con qué fin figuraban esos retratos en aquel altar? ¿Estarían bajo las influencias de las hechicerías del brujo criollo? Al retirarnos observamos con sarcástica sonrisa el ajuar de la sala de recibo de aquella Sociedad de Socorros Mútuos, instrucción y recreo entre el que figuraba un piano cuyas teclas recorría, gozosa, una mujer de color, é hicimos nuevos propósitos de contribuir á la extirpación de tan criminal superchería (1908: 84-5).

La reacción del detective Roche muestra el efecto de la fotografía como actualización de la presencia del sujeto fotografiado, es decir, como manifestación de una noesis que recuerda los procedimientos mágicos de imitación o contagio, según la distinción clásica de Frazer, basada en los principios de similitud y de contacto como categorías del entendimiento (Keck, 2002). Sin embargo, con la fotografía esta diferencia se desvanece, ya que esta imagen concentra las dos posibilidades: transporta una semejanza (un valor metafórico) y, a la vez, por el hecho de realizarse el contacto en una relación temporal, al capturar un instante de vida (un valor metonímico), puede extenderse por contagio a la totalidad de la vida de lo que representa. Esta distinción nos recuerda el doble valor, icónico e indicial que puede tener el retrato fotográfico. Este doble potencial de la fotografía puede explicar la predisposición del policía para ver en estas fotos los indicios de una actividad mágica, donde la presencia de un ícono se vuelve indicio de una concepción aurática de la imagen, índice de un rito o culto, o sea de un potencial delito. Esto porque la afirmación indicial posibilita una forma contagiosa de la magia, contagio al cual está afecto el detective, al proyectar un valor de uso del retrato como índice de contagio mágico sobre individuos capturados en imágenes, y por lo tanto potencialmente víctimas de la semejanza. Roche no puede impedirse ver los retratos de los niños, la mujer negra, el altar y el piano como índices de la escena de un crimen que va a ocurrir, índices que lo chocan como anuncio de muerte por una brujería que reúne contagio y semejanza. Por una suerte de mimesis con la figura de aquellos que persigue (los brujos asesinos de la criminología afrocubana), Roche sospecha una gran "superchería», atrapado como está por el artificio de la imagen y la puesta en escena de su valor de culto: la muerte futura del retratado, el anuncio de una catástrofe cercana. Proyecta así, sobre el destino de estos niños, la suerte que el régimen judicial reservó para Bocú. La «campaña contra la brujería» lleva a estos agentes a instalarse en el mismo plano de representación y afecto que sus enemigos quiméricos. Es lo que Stephan Palmié identifica como la «salación científica» que practican los agentes criminológicos: conjurar los poderes de los brujos por medio de procedimientos que relevan de las mismas lógicas y formas de trabajo sobre la potencia de los objetos, las imágenes y los seres vivos. Al compartir con sus adversarios una misma concepción animista de los objetos inanimados y las representaciones, los antropólogos son afectados por el efecto aurático de las imágenes que intentan conjurar con sus propios procedimientos de poder-saber. El Museo de Antropología, donde van a parar los cráneos, los documentos, las fotografías, y los objetos saqueados de los «templos brujos» por la policía, se asemeja así a un gigantesco caldero mágico o nganga congo (2002: 254-9). ${ }^{5}$ En torno a la imagen fotográfica se enfrentan así magos y científicos, con sus prácticas conjuratorias, sus discursos de incantación y sus sistemas de clasificación.

La nganga en la religión del palo monte o congo en Cuba es el caldero que contiene las fuerzas y espíritus que actúan a favor del dueño de la nganga. En este recipiente de metal pueden estar contenidos elementos 
Fernando Ortiz alentará esta operación de «saqueo del templo brujo», declarando la utilidad de los objetos de los brujos para el estudio científico:

desde luego, aun cuando no se llegase a una condena, deberían decomisarse los ídolos, imágenes, collares, fetiches, altares, chumbas y demás enseres y cachivaches de los templos brujos, los cuales, al menos los más característicos, en vez de ser destruidos como se ha hecho hasta ahora, debieran ser destinados al museo de antropología de la universidad nacional (1995: 196).

Este museo intentaba emular el Museo del Crimen que mantenía Lombroso en Turín, el cual se benefició del envío de varios «fetiches» y amuletos afrocubanos por parte de Ortiz (en Bueno, 1998: 105-7). ${ }^{6}$

Sin embargo, por ser reconocida la libertad de culto en la Constitución de 1901 (bajo el modelo de las garantías constitucionales norteamericanas), estos objetos eran también preciados como piezas a convicción para aprisionar e inculpar a los sacerdotes africanos por otros motivos legales: los materiales perecibles de las ofrendas por ejemplo servían para la inculpación por atentado a la higiene (Bronfman, 2002a), mientras que los «fetiches» constituían los indicios de la actividad del brujo, indicios que Ortiz se empeña en reproducir en las ilustraciones de su libro, en un intento por capturar la lectura del retrato de Bocú por medio de un contexto visual «fetichista» (amuletos, collares, estatuillas, calderos). De esta manera, la policía trabajaba para los antropólogos, decomisando los «fetiches» de sus investigaciones, y los antropólogos trabajaban para la policía, construyendo la matriz de clasificaciones que permitirían la identificación del «tipo criminal». Las descripciones del «templo brujo» ofrecidas por Ortiz y la casi totalidad de su obra de 1906, incluyendo toda la serie de ilustraciones, pueden leerse como un detallado studium (en el sentido barthiano) policíaco del retrato de Domingo Bocourt. Esto incluye las descripciones del «bohío del brujo Bocú»:

se distinguía también [el bohío] de todos los demás inmediatos no sólo por estar todo él blanqueado [...] sino por una gruesa cadena de hierro [...] a manera de baranda [...] probablemente un símbolo fetiche de Eleguá; o sea, del orisha maligno, a manera de barrera o guardiero contra la cosa mala» (1995: 84-5, subrayado del original).

Y también la descripción del altar de la casa-templo, cuyos símbolos católicos requerían un «ojo experto» que detectará el «disfraz» afrocubano:

el brujo Bocú, a pesar de ser —según parece- africano, tenía un altar ante el cual [...] se postraría el más fanático de los calambucos católicos [...] adornado con flores de papel. En el sitio preferente una estampa de Santa Bárbara, y a su alrededor las de la Virgen de Regla, de la Virgen de la Caridad del Cobre, del Niño Atocha, de la Virgen de las Mercedes, de la

de las fuerzas naturales (metal, tierra, agua, fuego, viento), y objetos varios, collares, plumas, cera, y también un cráneo recuperado en algún cementerio y que representa al muerto (nfumbi) que actúa a favor del iniciado (véase Palmié, 2002: 159-200).

6 El museo constituye así una pieza clave de la maquinaria antropológica de inclusión/exclusión y su organización de valores estéticos. Como señala Willy Thayer, «El origen del museo moderno está vinculado a la guillotina (Bataille), al corte, a lo que cae de un lado o del otro, a la topología, a la burocracia de fronteras». El museo de antropología en Cuba, produce la equivalencia entre objetos criminales y objetos africanos, un museo africanista como museo del crimen, ya que «como principio constructivo de la identidad nacional, el museo contribuye a la destrucción, construcción y redistribución de las culturas que considera [...] al mismo tiempo, como lugar del valor de exhibición, vuelve iguales fragmentos poco dados al principio de equivalencia» (Thayer, 2005: 287). 
Dolorosa y de San José. A cada lado del altar una oración. Ambas oraciones (que impresas llevaban también una imagen) eran asimismo católicas; llamada A la piedra imán la una, y a San Lázaro, sal del sepulcro la otra. Sobre el altar varias botellas de agua bendita y algunas ofrendas (85, cursivas del original).

Si todas estas descripciones funcionan como el studium del retrato, la práctica de lectura y escritura alfabética fue quizás la que más generaba «ruido» en las teorías de la inferioridad atávica afro-cubana. No es de extrañar entonces que la lámina del retrato sea acompañada del facsimil de una carta manuscrita del mismo Bocourt, único documento conocido de la práctica religiosa del sacerdote congo y de la organización social que se articula en torno al culto (lámina 1). La trascribo aquí in extenso:

Amigo pablo deseo se alle bien en union de todos por esta su c[a]sa no. hay nobedad à Dios gracias. amigo esta es para de cirte lo à quien te que la Muñeca cuesta 25 pesos sin faltar uno, boy a estar trabajando hasta el 31 bamos aber si Dios quiere como salimos con el fabor de Dios el negocio esta jorobado bus. que un pollo colorado Mañana à las doce y pasese lo a la muchacha por en cima vivo y su [ego] lo ma ta a bier to [en siban] de banda y [...] un guiso de por [...] como llo le dije y si [...] me las es criban oserba [... ...] para Mag da lena Lage à Melena del [Sun] y el pollo lo manda bo tar bocarriba y le echa tres centa bo él [...] Sin mas por hoy su amigo Domingo Bocourt

San Cristobal septiembre [...] de 1904

el pollo lo bota al pie de la ceiba que es ta en la lluca. ${ }^{7}$

No se conocen otros documentos de Bocourt, aunque según Ortiz, se le decomisó una importante cantidad de correspondencia, cuya desclasificación queda pendiente. Ortiz no se interesa mayormente en esta carta, ni en las otras, salvo para preguntarse por las prácticas de «oniromancia» por parte de los sacerdotes africanos («varias cartas escritas por clientes fueron decomisadas al brujo Bocú, en una de las cuales se informaba un sueño y solicitaba su interpretación», 1995: 112), y para confirmar que:

El progreso, formal al menos, se extiende y toca a todas las manifestaciones de la brujería [...] Hoy día hay brujos que, incluso por escrito, encargan sus recetas. El célebre Bocú recibía dos o tres cartas por día. Lo que muestra que la enseñanza del alfabeto y la escritura no significa nada para la cultura nacional, sin más bases sólidas de progreso intelectual. Es decir, que la instrucción — como lo ha mostrado la escuela criminológica positivista- es un arma que puede ser usada a favor del bien como a favor del delito (145).

Estas conclusiones llevarán a Ortiz a incluir en su plan de lucha contra la brujería «la prohibición de venta de rezos indiscutiblemente atávicos e incluso delictuales, como el del Justo Juez, de la Piedra Iman, etc., que hoy se venden públicamente» (199). Y sin embargo, el mismo autor publica tres variantes de la Oración al Justo Juez (215-6), y las compara al uso talismánico de la escritura en la geomancia africana ( 80 y 136). Esto muestra el tipo de paradojas en que se encuentra atrapado Ortiz, compelido por la ciencia a publicar lo que su política de «defensa social» le recomienda censurar.

Facsímil en Ortiz (1995: s/p, ilustración 43), con el título «Carta autógrafa del negro Bocú». 
No podemos detenernos aquí en el amplio debate y corpus criminológico sobre la práctica del tatuaje, que usará profusamente el recurso fotográfico para analizar esta forma de escritura practicada por los «delincuentes» sobre sus propios cuerpos (Lombroso, 1887; Bertillon, 1888; Martinez, 1899; Castellanos, 1915; Pavez, 2007). En cualquier caso, hay que tener en cuenta que la fotografía de Domingo Bocourt, icono principal de la obra princeps de Ortiz, es sólo la más visible de un trabajo de producción y acumulación de numerosos documentos fotográficos que los antropólogos cubanos efectuaban al menos desde la última década del siglo XIX, cuando el médico Luis Montané visitaba, examinaba y fotografiaba los homosexuales en las cárceles de La Habana (Montané, 1890; Marqués de Armas, 2003). Fernando Ortiz se interesará en estas colecciones iconográficas judiciales, al punto que constituirá una notable colección de estas imágenes en su archivo privado, bajo el rótulo «Negros-tatuajes». Sin embargo, no publicará ninguna de estas fotografías, por considerar quizás su "valor exhibitivo» demasiado «obsceno", prefiriendo así preservar su valor de culto "científico», complementario al valor icónico de la fotografía de un «tipo criminal» en particular (la de Bocú). En cambio, otros criminólogos hicieron uso profuso del archivo policial para la afirmación indicial de sus categorías criminológicas, lo que permite asociar la «afirmación indicial» a un valor de exhibición de la fotografía. Después del detective Roche Monteagudo (1908) ya citado, el más prolífico de estos criminólogos fue el mulato Israel Castellanos.

\section{EL IMAGINARIO VISUAL DE CASTELLANOS: IMAGEN INDICIAL Y ESTÉTICA DE LA CADAVERIZACIÓN}

Israel Castellanos aparece decisivamente en la escena criminológica cubana en 1914, como discípulo aventajado de Fernando Ortiz. Ese año, el joven médico publica varios artículos y folletos («El tipo brujo», "El carnaval como revelador de la inferioridad psíquica de una raza» y "La mandíbula del criminal») y un Atlas con 57 láminas, donde presenta una importante colección iconográfica, siguiendo el modelo del Atlas criminal lombrosiano, modelo de colección y publicación iconográfica que también encontramos en los volúmenes de la Iconografía de la Salpetrière.

Ortiz, Roche y Castellanos recogieron sus documentos fotográficos de las mismas fuentes. Se trata de dos equipos de registro institucional: el de la Oficina de Identificación Dactilo-fotográfica de J.F. Steegeers, fotógrafo de las cárceles cubanas, y el que informa Castellanos en la presentación de su Atlas criminal, que trabaja más bien con los fotógrafos del "asilo de dementes» y de la policía secreta. ${ }^{8}$ Vemos así cómo estos antropólogos criminales, junto a los médicos «alienistas»y "post-alienistas», comparten con los dispositivos de normalización y control social un interés por la fotografía como «un procedimiento experimental (instrumento de laboratorio), un procedimiento museológi-

\footnotetext{
«La labor para que fuese lo más completo posible el presente Atlas, no ha sido personal, sino casi colectiva, cuanto a la adquisición de fotografías y grabados se refiere. He sido ayudado entusiasta y eficazmente por Alfredo Alacán Berriel, dignísimo ex-detective y Director de la Gaceta judicial y de policía, por el Dr. Manuel Varona Suarez, ex-secretario de Sanidad y Beneficencia, por el Dr. Américo Feria, sub-director del Asilo de Dementes de Cuba, por el Lco. Julio Smith, por Juan Valinotti, fotógrafo de la Secreta y por Francisco Mein, fotógrafo del Frenocomio de Mazorra» (Castellanos, 1914a: 2).
} 
co (archivo científico), y un procedimiento de enseñanza (un instrumento de difusión)» (Didi-Huberman, 2007: 48). La aparición de Castellanos constituye un paso importante en la visibilización del corpus fotográfico criminológico, pero a diferencia de Dumont o de Ortiz, no organiza el material fotográfico por individualidades con nombre propio, rompiendo así con los relatos épicos, literarios, etnográficos o policiales que se organizan en torno a las huellas del criminal.

Sobre el Atlas, opus princeps que lo vuelve célebre antes de haber terminado sus estudios de medicina, Ortiz escribirá:

El autor promete ser figura de relieve en nuestra literatura sociológica, si persiste en sus empeños intelectuales polarizados hacia la observación positivista de las cosas de nuestra tierra [E]s lombrosiano y trata de reflejar las teorías lombrosianas sobre nuestra fauna criminal [...] Nos complacemos en saludar un nuevo cultivador de la Antropología Criminal, tan abandonada entre nosotros: abandono éste tanto más injustificado y triste cuando que en Cuba, por el mosaico étnico de su básica constitución social, se encuentra un campo preciosísimo, casi totalmente por explotar (Ortiz, 1914, cit. en Marqués de Armas, 2004: nota 9). ${ }^{9}$

Años después, en sus "confidencias», Castellanos explicará que se inició de autodidacta, visitando cárceles, manicomios, correccionales. Ahí, señala, «medí locos, delincuentes, homicidas, meretrices, pesé mandíbulas, mensuré cráneos, busqué y coleccioné fotografías, estudié tatuajes, tomé impresiones palmares, e hice pesquisas en todo el organismo humano» (Castellanos, 1917, en Galera, 1988: 84). En la presentación de su Atlas, el joven profesor explica claramente su opción por la colección gráfica:

La ciencia del criminal exige - más que ninguna otra- el complemento de la ilustración gráfica, y mucho más cuando es una escuela que, —como la antropológica- blasona de positivista y experimental. Por eso no he vacilado, no obstante la pequeñez del volumen doctrinal, en la publicación del presente Atlas. Lombroso dice que éste es siempre, no solo una parte integrante de la obra, sino la más importante de ella. [...] El arte anestesia las tosquedades de la realidad. La prehistórica facie del criminal, troquelada en el delicado glosar de la literatura, resulta una mascarilla de bronce en bajo relieve. Los caracteres somáticos inherentes al degenerado o al salvaje, se atenúan o desaparecen si no se le presenta con la severa fraseología de la Ciencia. Pero, así como el estilismo literario peca de dúctil, el vocabulario científico peca de rigidez; pero encuentra en la fotografía y en el grabado, una ayuda eficaz y valiosa. [...] la forma más apodíctica de hacer ostensible un tipo, de una raza o variedad cualquiera, es haciendo conocer conjuntamente, para su comprobación, los rasgos o caracteres del susodicho tipo. La crítica empírica hallará en el Atlas un arma más poderosa, que todo el cúmulo de silogismos por ella empleados para combatir la escuela criminológica positivista. Veinte volúmenes de argumentaciones sociológicas caen desacreditados con una sola colección de fotografías (Castellanos, 1914a: 1-2).

9 En 1916, con ocasión de su trabajo de traducción y notas del libro de Dumont, Ortiz da más detalles de su colaborador Castellanos: «antes de comenzar los estudios de bachiller, ya Castellanos escribía de criminología tan concienzudos trabajos que merecía el título de Profesor del Instituto Criminológico de Madrid. Estudió, y ahora está terminando la carrera de Medicina en nuestra Universidad Nacional. Acaba de ser nombrado Director del Gabinete Nacional de Identificación. Y es un joven de cerebro robusto, poderoso, que tiene, como no muchos en Cuba, un sentido científico orientado por un franco y vigoroso positivismo, y ya recomendado por originales trabajos, publicados en Cuba y el extranjero" (Dumont, 1922: 6). 
Contra la prosa literaria y contra la prosa científica, la marca fotográfica ofrece a Castellanos las "pruebas» irrefutables de la existencia de tipos, clases y razas. Como con la dactiloscopia que en los mismos años Fernando Ortiz se empeña en defender como método infalible de identificación del «nombre antropológico» de los ciudadanos (Ortiz, 1913a; 1913b), Castellanos valoriza en la técnica fotográfica la posibilidad de ahorrarse toda mediación del lenguaje. La fotografía se le presenta como una escritura transparente de la naturaleza. La técnica se vuelve la única mediación entre la realidad «natural» de los tipos y clases y la verdad de la ciencia como sistematización y jerarquización de estas categorías. En este sentido, el Atlas constituye un «arma más poderosa» que la crítica, porque no requeriría de mediaciones lingüísticas (literarias o "fraseológicas») para acreditar las tesis positivistas. Se trata aquí por supuesto de un simulacro naturalista de transparencia, ya que todas las fotografías son acompañadas por textos donde el criminólogo despliega categorías que evita justificar o argumentar. Y son precisamente estos comentarios de las imágenes que producen las operaciones de clasificación: la leyenda de la imagen dirige la mirada del observador hacia un punctum predefinido como el indicio decisivo que hace de una forma visual el rasgo de un tipo o una clase, produciendo así un estereotipo. El índice de la leyenda produce el punctum de la foto como efecto de la descripción.

Así, por ejemplo, una fotografía (lámina 2) cuya leyenda señala:

Figura 17: Negro criminal cubano, nótese la acentuada dolicoprosopia que presenta; la distancia enorme del punto sub-nasal al alveolar y la robustez del maxiliar inferior. Condenado por homicidio. La exageración de los caracteres típicos de su raza, aún dentro de su inferioridad étnica, le hacen un ser aparte y degradado de ella (Castellanos, 1914a: 8).

Y para reforzar su control sobre la lectura de esta imagen, Castellanos recurre a la autoridad del abogado Enricco Ferri, que había insistido en la observación de la facies como carácter más importante que el cráneo para la determinación de la inferioridad racial, ya que para ellos la facies es el «rostro asignado al régimen de la representación» (Didi-Huberman, 2007: 89). ${ }^{10}$ Así, los retratos de los brujos son llamados a dar cuenta de un «régimen de representación» cuyos valores estéticos son preestablecidos para transformar el «anacronismo de las imágenes» (Didi-Huberman, 2008) en anacronismo de un tipo social presentado como estereotipo.

Podemos citar otro ejemplo de estos procedimientos, del artículo publicado el mismo año, «La mandíbula del criminal» (1914c). Este opúsculo presenta dos láminas (lámina 3). La primera con una mandíbula humana y una de gorila, la segunda de dos sujetos negros, de frente y de perfil, con un comentario sugerente: "Negro con mandíbula enorme». Y el conjunto es titulado "CRIMINALES». Luego de la exposición de estas "pruebas científicas», el artículo llama a aplicar sin piedad la pena capital para los «salvajes» afrocubanos (Castellanos, 1914c). El dispositivo textual aplicado a estas fotografías pone en evidencia el método que guía el sistema clasificatorio criminológico: los rostros anónimos son puestos al servicio de un orden, el de la pertenencia a un «tipo», explotando

10 «Enricco Ferri, en L'omicidio [1885], insiste sobre el predominio de la cara sobre el cráneo como carácter de inferioridad, porque no tan solamente es particular en las razas inferiores y salvajes, sino que recuerda el enorme desarrollo de la cara del caballo, en relación con ovoide craneano. Este carácter lo encontró muy difundido entre los homicidas. Los homicidas cubanos, según mis observaciones, presentan la dolicoprosopia (cara extremadamente alargada)» (Castellanos, 1914: 8-9). 


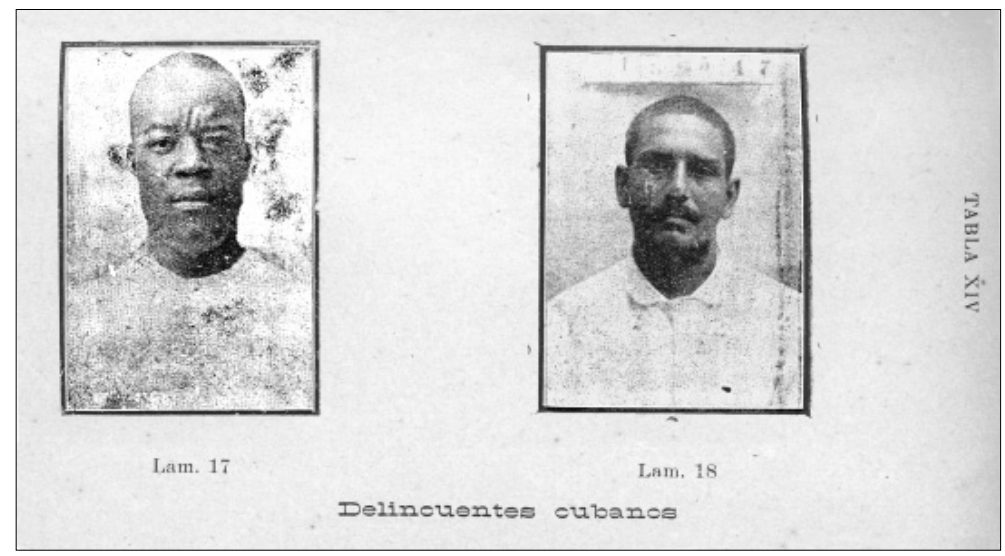

2. «Delincuentes cubanos» (Castellanos, 1914a).

así «la posibilidad figurativa de generalización del caso en un cuadro» (Didi-Huberman, 2007). En esta lógica, es clave la oclusión del nombre propio, que permite la descripción de un ejemplar subsumido en una serie, la producción «técnica» de una clase. La máquina antropológica produce así un "anonimal», por un doble proceso de "anonimación» y «animalización» del sujeto. La puesta en serie de los ejemplares y la manipulación del punctum de la imagen por su captura en el studium de la «descripción finita» de un conjunto permitirá entonces que surja desde estas fotos la connotación criminal de la clase denotada: la del «brujo afrocubano». Los criminólogos pueden entonces presentarse como los únicos capaces de detectar los indicios de pertenencia a esta clase, indicios de los cuales registran la huella como prueba de existencia de la misma.

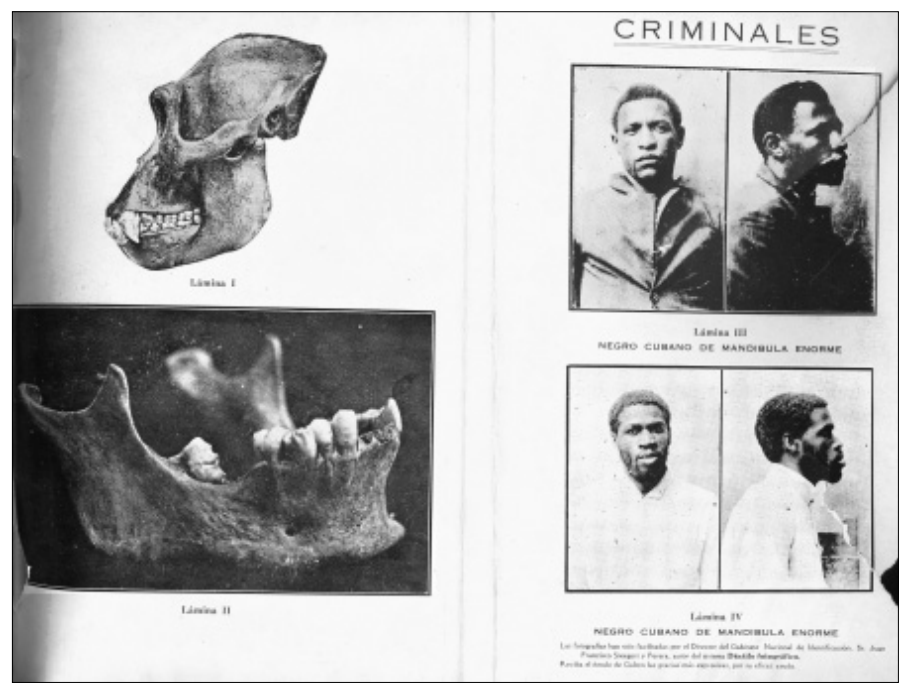

3. «Criminales: negro cubano de mandíbula enorme» (Castellanos, 1914c). 


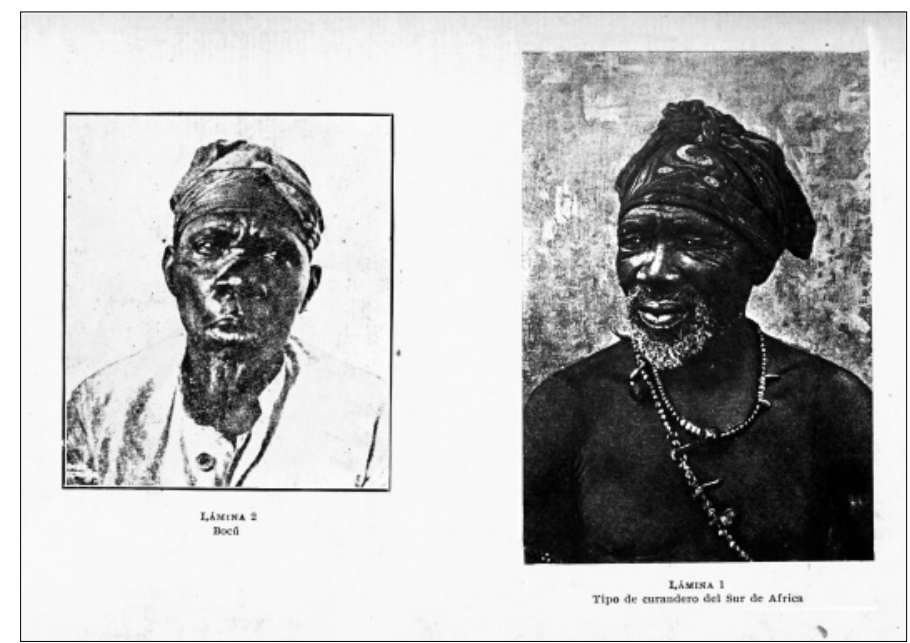

4. «Lam. 2: Bocú/ lam. 1: tipo de curandero del Sur de África» (Castellanos, 1914b).

De las numerosas publicaciones cortas realizadas por Castellanos el año 1914, «El tipo brujo", dedicado al "sabio maestro doctor Fernando Ortiz», nos parece el ejemplo más logrado de los procedimientos del médico para la producción de un sistema de clasificación basado en la complementación de varias fuentes, medidas y fotografías. Pareciera incluso que Castellanos desarrolla este trabajo retomando casi al pie de la letra las recomendaciones que Lombroso le señalaba a Ortiz en su famosa carta-prólogo para Hampa afrocubana. Los negros brujos (1906): «No tengo nada que sugerirle en cuanto a sus futuras investigaciones de etnografía criminal, si no es la adquisición de datos sobre las anomalías cranianas, fisionómicas y de la sensibilidad táctil en un número determinado de delincuentes y brujos, y en un mismo número de negros normales» (Lombroso, en Ortiz, 1995: 1).

El estudio del «tipo brujo» invoca la autoridad de autores como Lombroso («los salvajes no tienen tipo criminal, porque en ellos la inferioridad humana ha llegado a su límite»), Tylor («el brujo es un sobreviviente»), Ortiz («el brujo es un criminal nato»), Lubbock («el brujo es de buena fe»), y algunos «misioneros africanistas» citados por Lubbock u Ortiz. Castellanos no toma ninguna distancia crítica con sus fuentes: «Las descripciones que los misioneros y etnólogos hacen del sacerdote africano es, con ligeras variantes, la fotografía de nuestros brujos»(Castellanos, 1914b: 9). Las descripciones son leídas como fotografías y las más de cien fotografías con las que trabaja, como la descripción estadística de un tipo, lo que recuerda los métodos propagados por Arthur Batut para la definición de los «tipos» y «razas» a partir de la superposición de numerosas fotografías de las cuales emergerían ciertos rasgos generales (Batut, 1887). Entre estas cien imágenes incluye los cuatro brujos «que dio a conocer Ortiz» en su obra (se trata de Bocourt, Victor Molina, Juan Cabangas y Ruperto Ponce, aunque los últimos tres son sólo mencionados por Ortiz). Para Castellanos, el «tipo brujo» debe responder a una construcción disciplinaria que está llamada a tener sus propios especialistas: «Hablamos del tipo brujo como el psiquiatra nos habla del loco moral, el patólogo del tipo escrofuloso, el antropólogo del tipo étnico, el criminalista del tipo criminal» (1914b: 5). Y esta formación disciplinaria en torno a un «tipo antisocial» lo lleva a reconocer que 
el «tipo brujo» es todavía una «entidad abstracta», "cuyos caracteres físicos y síquicos nos son casi desconocidos». La fotografía criminal, especialmente el retrato de medio cuerpo de frente, se vuelve así el medio de producción concreta de una entidad abstracta. Propone entonces una comparación detallada del «tipo criminal» y el «tipo brujo»" para extraer las siguientes consecuencias (láminas 4, 5, 6 y 7).

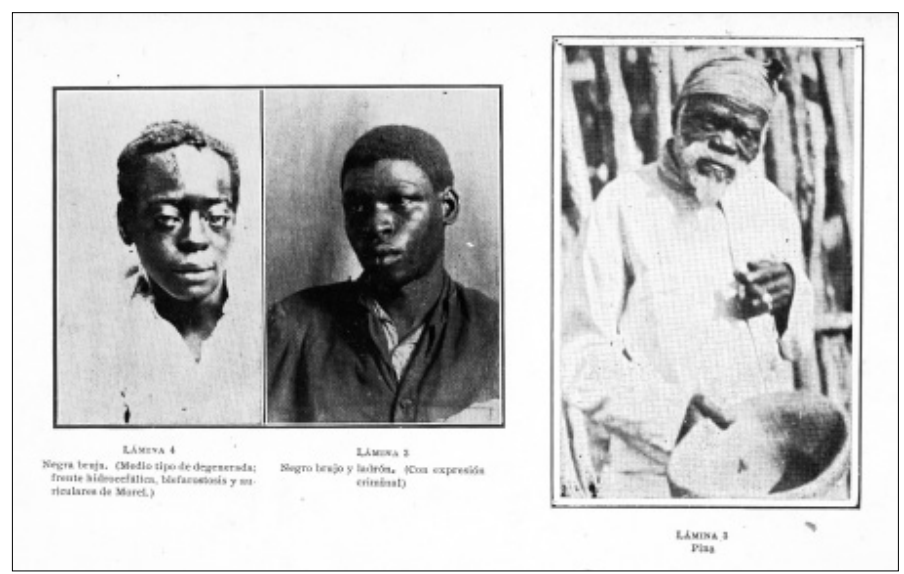

5. «Negra bruja/negro brujo/Pina» (Castellanos, 1914b).

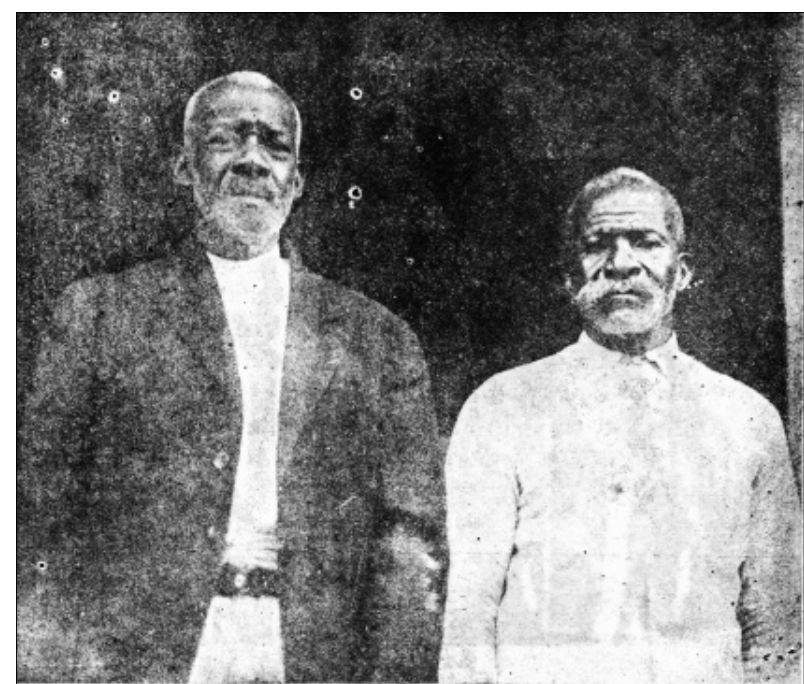

6. «Fetichistas afrocubanos con barba» (Castellanos, 1916b).

11 Compara los rasgos físicos siguientes: proporción de los senos frontales, mandíbulas enormes, prognatismo desmesurado, arrugas horizontales y verticales sobre la frente, arrugas naso-labiales profundas, asimetrías faciales, oreja de Wildermuth, oreja en asa, oreja sesil, ojos desiguales y oblicuos, menton cuadrado, microcefalia frontal, zigomas enormes, hipertrofia del lóbulo auricular, etc. (Castellanos, $1914 b: 5)$. 


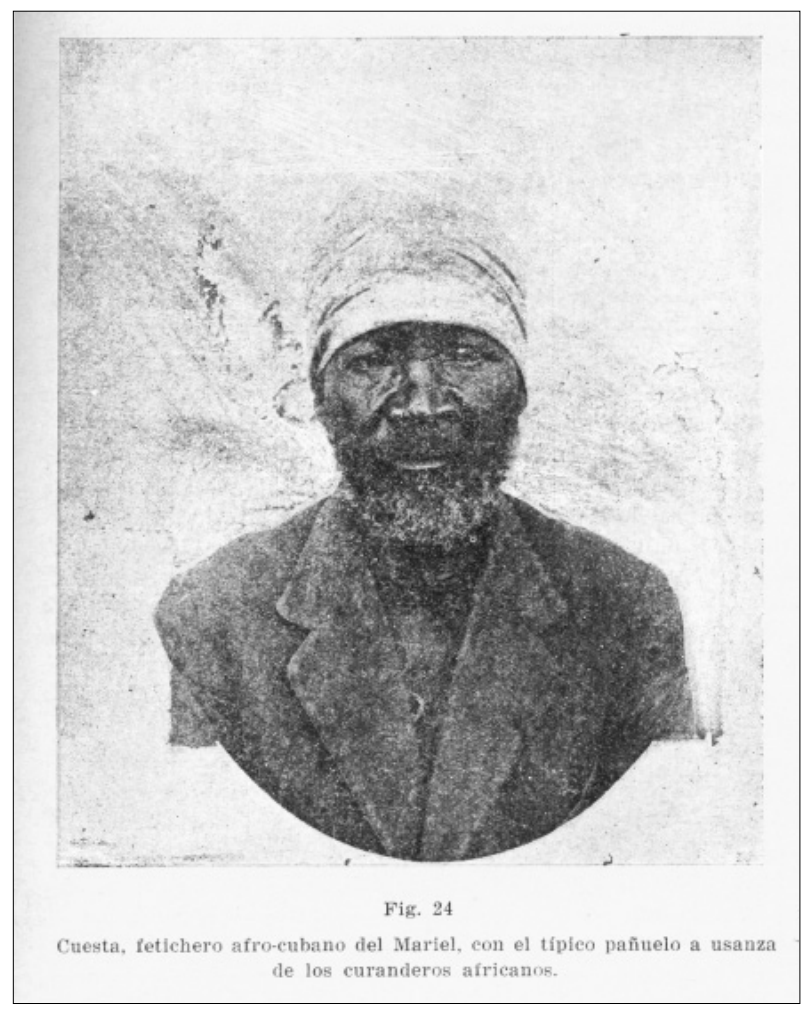

7. «Cuesta, fetichero afrocubano del Mariel» (Castellanos, 1936).

Primero, que los brujos «no exageran el tipo étnico». Para probarlo, invoca un nombre y un retrato conocido, el de Domingo Bocourt:

El célebre Bocú que da a conocer el Dr. Ortiz, únicamente exagera las arcadas cigomáticas y la distancia alveolo-subnasal. Todos los demás caracteres son normales en el negro. Las arrugas que presenta, teniendo en cuenta su edad, pueden considerarse normales. El único carácter mórbido que se observa en él es una ligera asimetría facial (Lám. 2) (Castellanos, 1914b: 6) (láminas 1 y 4).

Se puede leer que la mirada y la boca son los rasgos que más atraen la atención del médico. Los índices «mórbidos» señalados (la mirada, la boca, la posición del rostro) son claramente variables propias de la pose, de la puesta en escena en el estudio policial, y quizás incluso a una auto-puesta-en-escena de Bocourt. Se trata entonces de una «expresión» facial que Castellano fija en un rasgo inmutable, como si su mirada detectara como cámara fotográfica los rasgos indíciales de una clase (al igual que el médico Charcot observaba las «histéricas»). Aparte de estas «ligeras huellas» de "morbidez», la identificación física del "tipo brujo» le plantea problemas a Castellanos, ya que no logra encontrar "mandíbulas enormes", "arcadas superciliares», "frentes estrechos y fugitivos» ("caracteres más comunes entre los criminales»). Propondrá entonces, como los «caracteres más frecuentes del tipo brujo: asimetría facial, anómala; implantación de los ojos, grandes 
arcos cigomáticos, mentón plano, oreja de Wildermuth, hipertrofia de los lóbulos auriculares, arrugas nasolabiales profundas, auricular sesil, cigomas prominentes y prognatismo desmesurado» (5). Pero, como si él mismo dudara de esas observaciones, se vuelca hacia otro aspecto de los retratos: la autopresentación del cuerpo y rostro de los brujos. Observa que 17 brujos de su colección «tienen barba», al igual que Bocourt, Juan Pina y Victor Molina, en contraste con los delincuentes comunes, que no usarían barba. Agrega que todos aquellos a los cuales se les encontró "símbolos y baratijas» llevan barba (11); y luego nota los pañuelos en la cabeza: «El brujo cubano, en público, como el sacerdote africano, se cubre la cabeza; pero no con birrete de paja, sino con un pañuelo de vivos colores. Bocú, tiene envuelta la cabeza en un gran pañuelo, en la misma forma que lo usan los feticheros africanos» (10) (lámina 4).

Así, la estética del brujo presenta los signos que lo traicionan y condenan: la barba y el pañuelo como rasgos estéticos se vuelven indicios de una tendencia criminal, confirmando el intento criminológico por neutralizar la dimensión estética de estos significantes. Una vez establecidos los caracteres físicos de los «brujos», Castellanos retomará el retrato psicológico que había iniciado Fernando Ortiz: utilización de una «jerga sagrada», «buena fe en sus acciones», e incluso, esa tendencia a «negar sistemáticamente su condición de brujo», y aquí también, Bocourt es el caso-tipo ( «recordemos sus rechazos reiterado a confesarse un brujo-nato, pretendiendo ser cristiano", 12-3). La definición sicológica del tipo se completa así por los rasgos que diferencian a los brujos de los criminales y especialmente, de los ñañigos ${ }^{12}$ : los primeros son «retrasados», diferentes a los segundos que son «atávicos», el «tipo brujo es más bien sicológico que somático", la psicología del brujo ("pasiva», "hipócrita», "sometida», "parasitaria») es el "revés» del alma ñañiga («impulsiva», "violenta», «criminal», «bribona»). Y como coronación de su diagrama del «tipo brujo», Castellanos identifica en él el carácter epiléptico del criminal: «El brujo puede tener un substratum epileptoide, como la criminalidad nata en la concepción lombrosiana, y el brujo — dice el Dr. Ortiz- es un criminal nato» (15); "su delincuencia primitiva lo iguala al criminal congenito, por su religiosidad que tiene formas tan primordiales y por la epilepsia que reúne y funde - dice Lombroso- la gran familia criminal» (17-8). Como si su análisis pareciera demasiado condescendiente con el brujo, hasta inocentarlo de sus crímenes "morales", Castellanos logra, gracias al apoyo de sus dos maestros, subsumir el tipo en "la gran familia criminal», y de esta manera justificar su persecución y su eliminación física.

Porque para Castellanos es la ciencia (y por lo tanto la fotografía), y no los códigos legales, la que debe definir quién se hace merecedor de la pena capital: «el único ‘delincuenticida conocido es la pena capital, y esta se hizo no para la víctima de los Códigos, sino para la salvaje figura troquelada por la Criminología: Investiguemos el organismo de nuestros bárbaros, estudiemos nuestros salvajes!» (1914e: 8; véase Castellanos, 1916a y Marqués de Armas, 2002). No se trata aquí solamente de una defensa de la pena de muerte como método punitivo, sino de un deseo del antropólogo por tener a su disposición los cadáveres de los condenados, en una suerte de compulsión por estudiar, ya no la imagen fija del cuerpo, sino el cuerpo mismo fijado como objeto de «disección»:

12 «Nañigo» era el nombre de los miembros de sociedades secretas masculinas que aparecen en Cuba entre esclavos y negros libres a principios del siglo XIX. Se hicieron conocidos en la segunda mitad de ese siglo por enfrentarse a las autoridades policiales, y entre hermandades rivales. La sociedad se conoce hoy en día como «abakuá» (Pavez, 2007). 
Si nuestro estudio en vez de ser un análisis de 100 fotografías, fuese un examen positivo realizado sobre la plancha de disección, en las celdas de la cárcel o en las galeras del presidio, tendríamos provechosas conclusiones [...] Las anomalías fisionómicas no bastan por sí solas, para determinar y explicar el tipo brujo. El estudio del hechicero cubano no termina en el examen de 100 fotografías, por fecundos que sean sus resultados. Las ulteriores investigaciones decidirán el éxito o el fracaso de nuestras actuales pesquisas (Castellanos, 1914b: 19).

El uso de «la plancha de disección» tiene aquí varios sentidos. Como Ortiz, Castellanos piensa que quedan aún centenares de brujos africanos en Cuba, pero que éstos se encuentran condenados a desaparecer. Esta próxima desaparición de los «sobrevivientes» obliga a la ciencia a "hacer luz aun sobre las variedades extinguidas, desconocidas en nuestra actual constitución básica, para compenetrarnos mejor de nuestra historia y de nuestra evolución social» (Castellanos, 1914b: 19). Y para ilustrar este objetivo, Castellanos se aplica entonces al trabajo sobre los cadáveres, que ilustra con la publicación de fotografías de los rostros de Bocourt y Víctor Molina ejecutados por garrote (láminas 8 y 9), y de Sylvestre Erice (lámina 10) con el cual se había enfrentado en una polémica pública (Castellanos, 1916b y 1936; Palmié, 2002: 256-9). La publicación de estas imágenes quiere ilustrar el poder mortífero de la criminología en su búsqueda de «luz», y la concepción de la fotografía como "arma de la verdad», que persigue las «variedades» supuestamente «extintas» hasta tener la prueba efectiva de su «extinción».

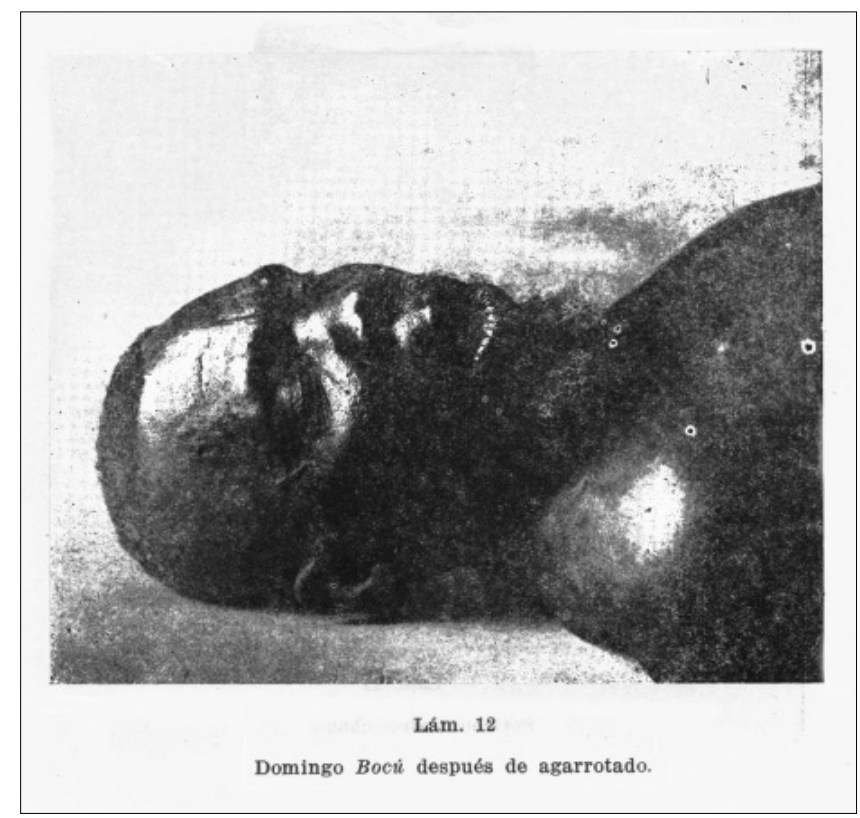

8. «Lám. 12: Domingo Bocú después de agarrotado» (Castellanos, 1916b). 


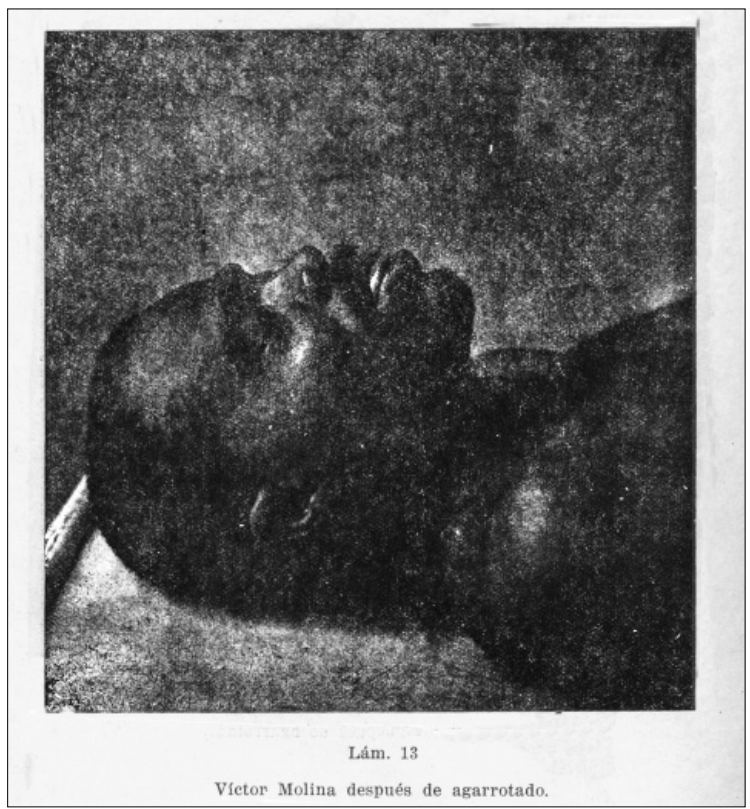

9. «Victor Molina después de agarrotado» (Castellanos, 1916b).

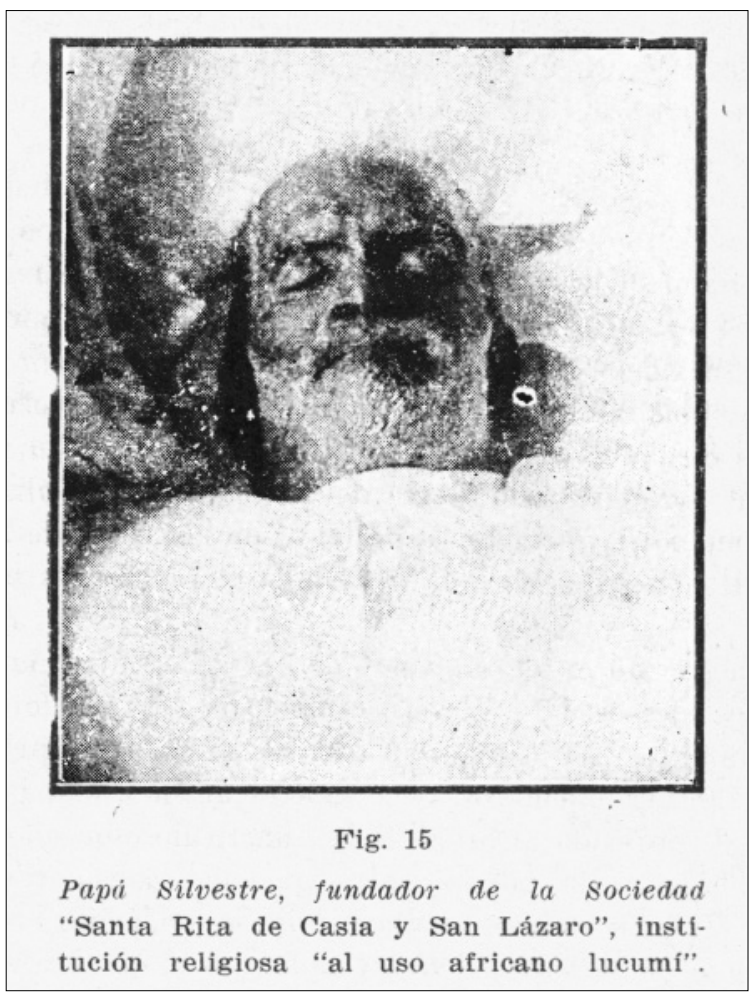

10. «Papá Silvestre, fundador de la Sociedad Santa Rita de Casia y San Lázaro». 


\section{ALGUNAS CONCLUSIONES}

Estas fotos de occisos pueden de hecho verse en serie con aquellas que los periódicos publicaban unos años antes, en 1912, del cadáver del general negro revolucionario Evaristo Estenoz, cuyo cuerpo aparecía abierto sobre una «plancha de disección» frente a los médicos que realizan la autopsia, y detrás de ellos, una masa de soldados para la pose. ${ }^{13}$ De los sacerdotes y políticos negros, se quería solo los cuerpos, como patrimonio científico. Su subjetividad histórica era en cambio un estorbo para la construcción nacional, como muestran los textos que acompañan invariablemente las fotografías. Con la publicación de las fotos de estos cadáveres, antropólogos y medios de comunicación parecen querer conjurar el "embrujo» de los retratos de Estenoz o Bocourt vivos, y de esta manera romper con el efecto del espectro más allá de la muerte, evitando un culto de su aura (tentación a la que Ortiz parece haber sucumbido). Se busca así neutralizar el «valor cultual» de la imagen del brujo, su «poder de levantar los ojos»(Benjamin, en Didi-Huberman, 2008: 351), por medio de dispositivos textuales que intentan bloquear la experiencia estética del retrato, transformándola en una experiencia del terror, como exhibición del maleficio y la muerte ante la mirada. Ya no se trata de mostrar la «belleza» de lo que ha muerto (el valor estético de lo que ya no es) (De Certeau, 1980) sino de la operación de dar muerte, de una potencia justificadora del dar muerte, que la ciencia ofrece a la sociedad cubana blanca. Ya no se trata solo de ejemplares folklóricos condenados a desaparecer sino de la prueba de una desaparición efectiva, como resultado de los dispositivos de normalización y control, de una aniquilación del aura del sacerdote o del revolucionario "de color», como logro de una acción de guerra, concertada entre el sistema judicial y la disciplina antropológica. La técnica fotográfica se vuelve así el principal instrumento de la puesta en escena del espectáculo necrológico del bio-poder-saber (Minovici, 1904). Esta auscultación y registro del cuerpo hasta el proceso de su "cadaverización», de manera de obtener la imagen más fija, la más «fotográfica», del «tipo» que se quiere hacer desaparecer, constituye el espectáculo, ya no de los castigos del suplicio medieval (Foucault, 1985) sino de las operaciones «científicas» de cirugía social sobre el organismo nacional, «enfermo» de africanismo y de mezclas bio-raciales. La fijación de clasificaciones sobre la imagen del brujo continúa así sobre su cuerpo inerte, que ya no puede nombrarse a sí mismo, y cuya cadaverización anuncia su pronta absorción por la naturaleza. La fotografía es así presentada como la huella indicial de su clasificación definitiva. El polimorfismo del cuerpo brujo, así como la polisemia del estatus civil de los afrocubanos se encuentra así fijada (Palmié, 2002: 245-6). Pero tratándose de algo más que un conjunto de cuerpos físicos, clasificables en tablas bio-médicas, estos "sobrevivientes» de África en Cuba dejaron sus imágenes y nombres inscritos como mitos, íconos, rumores y secretos, dispuestos y disponibles para re-emerger en los corpus de clase y de su conformación política e histórica. Más aún, es precisamente la experiencia de la mirada del retrato, la del afrocubano mirando al espectador, la que se actualiza en la historia, mientras que los dispositivos textuales que intentaron controlar esa experiencia, no nos hacen hoy ningún sentido. Por su anacronismo, estos retratos siguen alimentando la mi-

13 Sobre la masacre de los miembros del Partido Independiente de Color, levantados en reclamo de derechos civiles en 1912, ver Fernandez Robaina, 1994; Helg, 1996; Castro Fernández, 2002. 
rada de hoy, conjugando «el ahora y el otrora» (Didi-Huberman, 2008), mientras que los textos han sucumbido a su historicidad, quedando sus efectos relegados al pasado. Si los textos criminológicos fueron la condición de publicación de estas imágenes, hoy son ellas las que le dan algún sentido a los textos.

Para terminar, interesa destacar aquí la relación entre el texto africanista en la imagen fotográfica, relación que se encuentra ya en los orígenes fundacionales de la antropología médica en Cuba. Las fotografías de Dumont anuncian las transformaciones de las ciencias humanas en el siglo XIX señaladas por varios autores: la universalización de los procedimientos del «examen» médico como análisis de caso productor de documentos sobre los individuos (Foucault, 1966: 368-73; 1985: 217-23), la incorporación de la imagen fotográfica como equivalente técnico de la observación médica (Didi-Huberman, 2007: 45-50), y la consolidación de un "paradigma indiciario" como forma de conocimiento común a médicos, historiadores y detectives (Ginzburg, 1986). Estos usos de la fotografía plantean un uso no-cultual y una experiencia no-estética de la fotografía. El aparato textual con el que Dumont, Ortiz y Castellanos capturan las imágenes de los afrocubanos está orientado a la producción de un índice que estabilice la relación entre rasgos fisionómicos y anatómicos (registrados por la cámara) y rasgos sociales y culturales (definidos por la posición y presentación vestimentaria de los cuerpos: la barba y el pañuelo que destaca Castellanos como elementos «típicos» del brujo). Las leyendas adosadas a las fotografías son aquí dispositivos claves de la captura indicial, en la medida en que intentan gobernar la mirada de las imágenes. En el lenguaje de Barthes (1989), las leyendas constituyen un studium que orientan la mirada hacia un punctum específico de la fotografía, intentando el control de su spectrum. En el caso de Ortiz, es un libro completo, Los negros brujos, que funciona como studium de un retrato irrepetible. Como señala Didi-Huberman (2007: 59) respecto a la Iconographie de la Salpêtrière del médico Charcot, las leyendas ya no designan tanto el "atributo de un referente» (el «brujo afrocubano»), sino un "concepto» (el «tipo brujo»), cuyo referente singular, el «brujo Bocú», no es más que un atributo (láminas 1,4 y 8). Así, las leyendas cumplen la doble función asignada por Wittgenstein a los signos «deícticos»: el aprendizaje de la realidad sensible por el lenguaje (un «brujo afrocubano» es esto) y el aprendizaje del lenguaje por la realidad sensible (esto, es un «brujo afrocubano») (Virno, 2004: 82-5).

Evidentemente, más que de aprendizaje, se trata aquí de la indexación de ciertos cuerpos (más bien, la parte superior del cuerpo: rostro y busto) a categorías clasificatorias, para así lograr la operación por la cual los «casos» se incorporan en un cuadro de clasificación, presentando un conjunto de individuos como ejemplares de series tipológicas que, capturados y ordenados como índice, permiten afirmar los conceptos propuestos: el «atavismo africano», el «tipo brujo como criminal nato». Estas clasificaciones están inscritas por un principio de «reproductibilidad mecánica» de la realidad que es lo que la fotografía viene a afirmar como mimesis previa a la misma reproducción: en el auge de la reproductibilidad técnica, la realidad se vuelve fotografía incluso antes de su reproducción fotográfica. Castellanos llega al extremo de ver el archivo de fotografías como sucedáneo de los cadáveres que quisiera disecar; en su imaginario, los cuerpos son fotografías, reproducibles e inmutables. Por la «ideología mimética» que sustenta el analogon barthiano, la identificación de la realidad con la fotografía implica un "deberleer la identidad en la imagen» (Didi-Huberman, 2007: 78). Este deber identificatorio es 
condición del uso fotográfico para la producción de las clases y tipos, y es también quimera de la representación fija. Así, la fotografía acompaña no sólo la representación de las clases sociales — la burguesía, la clase media o la aristocracia (Barthes, 1989: 77)—, sino también la producción de las mismas como efectos de la fotografía y su operación de puesta en escena reproductible (Naranjo, 2006; Collingwood, 2009). La captura serial de la fotografía por la reproductibilidad mediática (prensa, archivos civiles y penales) constituyen la identidad como lo que es reproducible, objetivable y generalizable, en contra de la singularidad que orientaba los códigos estéticos del retrato pictórico como «identidad para sí, y no una cosa en sì (Nancy, 2006: 50). Si la producción artística de las clases sociales prolonga el valor de culto de los retratos fotográficos como íconos de su mitología fundacional, la producción científica de las clases (como razas o tipos) a partir de la fotografía se afirma en el valor de exhibición del rostro humano como índice técnicamente reproductible. Pero este intento de sujetar el noema fotográfico, de controlar su efecto de desaparición, de indexar su lejanía, parece condenado al fracaso, en la medida que el retrato es siempre lo que queda como resto de una leyenda, lo que resiste a la objetivación, por estar sujeto a una experiencia de la lejanía que es experiencia estética de lo sensible, antes que experiencia científica de lo inteligible.

En la etapa fundacional de la antropología cubana que acabamos de revisar, las lógicas de Ortiz y Castellanos se complementaron, por una suerte de reducción invertida en el marco de un mismo positivismo evolucionista, siendo ambos fascinados por la «belleza de lo muerto». Ambos contribuyeron a reforzar en los albores de la república una "prosa del terror» hacia los negros, ya centenaria, basada en tres grandes miedos raciales: el miedo a la «revolución negra», el miedo a la «brujería» negra, y el miedo a la «sexualidad» negra (Helg, 1996: 17-8). Al publicar los retratos de los negros brujos, Ortiz y Castellanos intentaron manejar las potenciales afecciones estéticas de estas imágenes, intentando neutralizar cualquier valor cultual y dirigir funcionalmente su valor de exhibición, predisponiendo la mirada a una experiencia del terror. Sin embargo, y quizás sin quererlo, contribuyeron a la producción de un valor icónico, que podría desprenderse de los dispositivos textuales con que intentaron capturarlas.

Pasando las décadas, mientras Castellanos encontrará en los cuerpos cadaverizados y en la «identificación civil» (de cuyo gabinete nacional será director hasta 1959) todo lo que satisfacía a su obsesión positivista, Ortiz iniciará pronto una búsqueda culturalista que lo llevará del folklorismo al espiritismo científico y luego al funcionalismo cultural (Ortiz, 1915; Díaz Quiñones, 1999; Pavez, 2007). A partir de esta deriva espiritualista, y preocupado por la transmutación de las almas, como metáfora de los procesos culturales, Ortiz se volverá un crítico positivista de la raciología europea y profundamente culturalista, al amparo del antropólogo Malinovsky, sumándose en las siguientes décadas al movimiento de defensa de la cultura afroamericana, y promoviendo la valoración estética de sus expresiones corporales, lingüísticas y religiosas. Este viraje podrá quizás ser leído como una muestra más de los efectos irreductibles de la experiencia estética africana sobre quien intentó reducirla a una pura exhibición museística de cultos desaparecidos. El retrato de Bocú parece anunciarnos que su desaparición no tendría lugar, y su mirada sigue acusando desde la lejanía que su ejecución no borraría su nombre ni podría silenciar su muerte. 


\section{REFERENCIAS}

Agamben, Giorgio. (2006). Lo abierto. El hombre y el animal. Buenos Aires: Adriana Hidalgo.

Barthes, Roland. (1989). La cámara lúcida. Nota sobre la fotografía. Buenos Aires: Paidós.

Batut, Arthur. (2006). La fotografía aplicada a la producción del tipo, de una familia, de una tribu o de una raza (1887). En Juan Naranjo (ed.), Fotografía, antropología y colonialismo (1845-2006) (pp. 92-101). Barcelona: Gustavo Gili.

Benjamin, Walter. (1991). L'œuvre d'art à l'époque de sa reproduction mécanisée. En Walter Benjamin, Ecrits français (pp. 177-250). París: Folio.

Bertillon, Alphonse. (1888). Les tatouages des malfaiteurs. Journal des débats. 26 agosto.

-. (1890). La Photographie judiciaire. París: Gauthier-Villars.

Bronfman, Alejandra. (2002a). Unsettled and Nomadic: Law, Anthropology and Race in Early Twentieth-Century Cuba. Maryland: Latin American Studies Center Working Papers 9.

-. (2002b). En plena Libertad y Democracia: Negros Brujos and the Social Question (1904-1919). Hispanic American Historical Review 82/3: 549-587.

Bueno, Salvador. (ed.). (1998). Fernando Ortiz: Italia y Cuba. La Habana: Fundación Fernando Ortiz.

Castellanos, Israel. (1914a). A través de la criminologia. Atlas. La Habana: Salas.

-. (1914b). "El tipo brujo (acotación de etnología criminal cubana)». Revista Bimestre Cubana 9/5: 94-105. La Habana: Imp. y Papelería La Universal.

-. (1914c). La mandíbula del criminal. La Habana: Imprenta Moderna.

-. (1915). El alacrán en los negros tatuados. La Habana: Imprenta y Papelería de Rambla, Bouza y Ca.

- (1916a). La pena de muerte bajo el punto de vista médico, Vida Nueva 8/1: 6-9. Obtenido el 10 de julio de 2009 desde <http://www.habanaelegante.com/Spring2002/ Panoptico.html>.

-. (1916b). La brujería y el ñañiguismo en Cuba desde el punto de vista médico legal. La Habana: Imprenta Lloredo.

- (1936). La lucha policíaca contra el fetichismo. Revista Técnica Policial y Penitenciaria, IV/2-3.

Castro Fernández, Silvio. (2002). La masacre de los Independientes de Color en 1912. La Habana: Ciencias Sociales.

Clifford, James. (1995). Dilemas de la cultura. Antropología, literatura y arte en la perspectiva posmoderna. Buenos Aires: Paidós.

Chávez Álvarez, Ernesto. (1991). El crimen de la niña Cecilia. La brujería en Cuba como fenómeno social (1902-1925). La Habana: Ciencias Sociales.

Collingwood-Selby, Elizabeth. (2009). La chispa fotográfica de un mundo en extinción. Papel Máquina. Revista de cultura I/2: 25-36.

De Certeau, Michel, Dominique Julia \& Jacques Revel. (1980). La beauté du mort. En M. de Certeau, La culture au pluriel. París: Seuil. 
De la Fuente, Alejandro. (2001). Mitos de democracia racial: Cuba 1900-1912. En Fernando Martínez H., Rebecca J. Scott \& Orlando García M., Espacios, silencios y los sentidos de la libertad. Cuba entre 1878 y 1912 (p. 235-269). La Habana: Unión \& Ciencias Sociales.

Delgado García, Gregorio. (2001). Los médicos y la antropología en Cuba. Cuadernos de historia de la salud pública 90. Obtenido el 14 de julio de 2009 desde <http://bvs. sld.cu/revistas/his/cua_90/his1490.htm>.

- (2003). Las primeras cuatro décadas de la Cátedra de Antropología en la Universidad de La Habana. Cuadernos de historia de la salud pública 95. Obtenido el 14 de julio de 2009 desde <http://bvs.sld.cu/revistas/his/his\%2095/hist0495.htm>.

Díaz Quiñones, Arcadio. (1999). Fernando Ortiz y Allan Kardec: espiritismo y transculturación. Catauro. Revista cubana de antropología 0: 14-31.

Didi-Huberman, Georges. (2007). La invención de la histeria. Charcot y la iconografía fotográfica de la Salpetriere. Madrid: Cátedra.

- (2008). Ante el tiempo. Historia del arte y anacronismo de las imágenes. Buenos Aires: Adriana Hidalgo.

Dumont, Henri. (1915-1916). Antropología y patología comparadas de los negros esclavos. Revista Bimestre Cubana X-XI. Trad. y notas de Israel Castellanos. Ed. de Fernando Ortiz.

- (1922). Antropología y patología comparadas de los negros esclavos. La Habana: Colección Cubana de Libros y Documentos Inéditos o Raros II.

Fernández Robaina, Tomás. (1994). El negro en Cuba 1902-1958. La Habana: Ciencias Sociales.

Foucault, Michel. (1966). Les mots et les choses. París: Gallimard.

-. (1985). Surveiller et punir. Naissance de la prison. París: Gallimard.

Fumagalli, Armando. (1996). El índice en la filosofía de Peirce. Anuario Filosófico XXIX/3: 1127-1440.

Galera Gómez, Andrés. (1988). El resurgir de una nueva escuela: Israel Castellanos y el atavismo del delito. Asclepio XL/2: 81-97.

Ginzburg, Carlo. (1986). Indicios. Raíces de un paradigma de inferencias indíciales. En Carlo Ginzburg, Mitos, emblemas, indicios. Morfología e historia (pp. 138-175). Barcelona: Gedisa.

Gould, Stephen Jay. (1997). La falsa medida del hombre. Barcelona: Crítica.

Helg, Aline. (1990). Fernando Ortiz ou la pseudoscience contre la sorcellerie africaine à Cuba. En La pensée métisse. Croyances africaines et rationalité occidentale en questions (pp. 241-250). París \& Genève: Presses Universitaires de France \& Cahiers de l'Institut Universitaire d'Etudes du Développement.

-. (1996). Our Rigthful Shared. The Afro Cuban Struggle for Equality 1886-1912. London \& North Carolina: Chapel Hill \& The University of North Carolina Press.

Keck, Fredéric. (2002). Les théories de la magie dans les traditions anthropologiques anglaise et française. Methodos 2: L'esprit. Mind/Geist. Obtenido el 14 de julio de 2009 desde <http://methodos.revues.org/document90.html>.

Legrand, Stéphane. (2003). Portraits du dégénéré en fou, en primitif, en enfant et finalement en artiste. Methodos 3: Figures de l'irrationnel. Obtenido el 10 de noviembre de 2006 desde <http://methodos.revues.org/document107.html>. 
Locard, Edmond. (I904). Reseña de La photographie judiciaire de R.A. Reis. Archives d'anthropologie criminelle, de criminologie et de psychologie normale et pathologique XIX/121: 71-73.

Lombroso, Cesare. (1887). L'Homme Criminel. Atlas. Paris: Felix Alcan. 32 planches.

- (1898). El delito, sus causas y remedios. Madrid: Librería General de Victoriano Suárez.

Londe, Albert. (1896). La fotografía moderna. En Juan Naranjo (ed.), Fotografía, antropología y colonialismo (1845-2006) (pp.155-163). Barcelona: Gustavo Gili, 2006.

Maresca, Sylvain. (1998). Les apparences de la vérité. Terrain 30: Le regard. Obtenido el 15 de diciembre de 2006 desde <http://terrain.revues.org/document3409.html>.

Martínez Baca, Francisco. (1899). Los tatuajes. Estudio psicológico y médico-legal en delincuentes y militares. México: Tipografía de la Oficina Impresora del Timbre.

Marqués de Armas, Pedro. (2002). Presentación a La pena de muerte bajo el punto de vista médico de Israel Castellanos. La Habana elegante: Panóptico habanero. Obtenido el 14 de julio de 2009 desde <http://www.habanaelegante.com/Spring2002/ Panoptico.html>.

-. (2003). Ronda nocturna: itinerarios del discurso homofóbico cubano. La Habana elegante: Panóptico habanero, invierno. Obtenido el 14 de julio de 2009 desde <http:// www.habanaelegante.com/Winter2003/Panoptico.html>.

-. (2004). Introducción a Psicología de las multitudes de Israel Castellanos. La Habana elegante: Panóptico habanero, verano. Obtenido el 14 de julio 2009 desde <http:// www.habanaelegante.com/Summer2004/Panoptico.html>.

Mestre, Aristides. (1999). La antropología en Cuba, Discurso leído en la sesión pública solemne celebrada por la Real Academia de Ciencias Médicas, Físicas y Naturales de La Habana, en conmemoración del treinta y tres aniversario de su fundación. [1894] Catauro. Revista cubana de antropología 0, julio-diciembre.

Minovici, Nicolas. (1904). Nouveaux procédés de photographie des cadavres. Archives d'anthropologie criminelle, de criminologie et de psychologie normale et pathologique XIX/121: 842-862.

Montané, Luis. (1890). La pederastia en Cuba. El Progreso Médico (pp. 117-125). Obtenido el 14 de julio de 2009 desde <http://www.habanaelegante.com/Winter2003/ Panoptico.html>.

-. (1909). Rapport sur l'état des sciences anthropologiques à Cuba. Bulletins et mémoires de la Société d'Anthropologie de Paris 5/10: 16.

Muchielli, Laurent. (1998). La découverte du social. Naissance de la sociologie en France 1870-1914. París: La découverte.

—. (2000). Criminologie, hygiénisme et eugénisme en France (1870-1914) : débats médicaux sur l'élimination des criminels réputés «incorrigibles». Revue d'bistoire des sciences humaines 3: 57-89.

Nancy, Jean-Luc. (2006). La mirada del retrato. Buenos Aires: Amorrortu.

Naranjo, Juan. (ed.). (2006). Fotografía, antropología y colonialismo (1845-2006). Barcelona: Gustavo Gili.

Ortiz, Fernando. (1913a). La identificación dactiloscópica. Informe de policiología y de derecho público, seguido de las instrucciones técnicas para la práctica de la identificación y del decreto orgánico no 1173 de 1911. La Habana: Imprenta La Universal. Ruiz and Co. 
-. (1913b). Instrucciones técnicas de identificación. Sistema Dactilofotográfico, patentado en Cuba por Juan Francisco Steegers y Perera. Oficial perito en dactiloscopia y director del Gabinete Nacional de Identificación. La Habana: Imprenta La Universal.

- (1915). La filosofía penal de los espiritistas. Estudio de filosofía jurídica, La Habana: La Universal.

- (1916). Hampa afrocubana: los negros esclavos. Estudio sociológico y de derecho público. La Habana: Revista Bimestre Cubana.

-. (1995). Los negros brujos. Hampa afrocubana. [1906] Ed. de Isaac Barreal. La Habana: Ciencias Sociales. Incluye carta-prólogo de Cesare Lombroso.

Palmié, Stephan. (2002). Wizards and Scientists. Explorations in Afro-Cuban Modernity and Tradition. Durham \& London: Duke University Press.

Pavez, Jorge. (2007). Africanismes à Cuba. Textes, images et classes. Tesis para optar al grado de Doctor en sociología con mención en ciencias sociales. Ecole des Hautes Etudes en Sciences Sociales (Francia).

Piazza, Pierre. (2000). La fabrique «bertillonienne» de l'identité. Labyrinthe 6: 33-50. Consultado el 14 de julio 2009. Obtenido desde <http://revuelabyrinthe.org/document453.html>.

Pick, Daniel. Faces of Degeneration. A European Disorder, c. 1848-1918. Cambridge (UK): Cambridge University Press.

Poole, Deborah. (2000). Visión, raza y modernidad. Una economía visual del mundo andino de imágenes. Lima: Sur Casa de Estudios del Socialismo.

Roche Monteagudo, Rafael. (1908). La policía y sus misterios en Cuba. La Habana: Imprenta La Prueba.

Stocking Jr., George W. (1968). Race, Culture, and Evolution. Essays in the History of Anthropology, Chicago \& London: University of Chicago Press.

Thayer, William. (2005). El museo como campo expandido. Revista de la Academia, 10: 285-299.

Tylor, Edward B. (1977). La civilización primitiva (1871). En F. Mateo (ed.), Los orígenes de la antropología, Darwin, Morgan y Tylor. Buenos Aires: Centro editor de América Latina.

Urías Horcasitas, Beatriz. (2000). Indígena y criminal. Interpretaciones del derecho y la antropología en México 1871-1921. México: Universidad Iberoamericana.

Virilio, Paul. (1989). La máquina de visión. Barcelona: Cátedra.

Virno, Paolo. (2004). Palabras con palabras. Poderes y limites del lenguaje. Buenos Aires: Paidos.

Recepción: agosto de 2009

Aceptación: octubre de 2009 